\title{
Nilai Tambah VCO Pada Unit Bisnis Agroindustri "Andana" di Kabupaten Lombok Utara
}

\author{
Tajidan*, Halil, Efendy, FX Edy Fernandez \\ Program Studi Agribisnis, Fakultas Pertanian, Universitas Mataram, Mataram, Indonesia
}

\author{
Article history \\ Received: 29 Agustus 2019 \\ Revised: 9 Setember 2019 \\ Accepted: 7 Oktober 2019 \\ *Corresponding Author: \\ Tajidan, \\ Program Studi Agribisnis, \\ Fakultas Pertanian, \\ Universitas Mataram, \\ Mataram, Indonesia \\ Email: tajidan@unram.ac.id
}

\begin{abstract}
Community service aims to improve understanding and application of financial management in the "Andana" VCO agroindustry business unit, and measuring the performance of its financing. Community service is carried out using the literasi, tutorial and assistance method. Tutorial participants' understanding of financial management is measured from the results of the pre test and post test, while the application of financial management is assessed by financial inclusion, and financing performance is measured using a value added analysis tool. The results of community service activities show that financial management understanding has increased from 77,69 to 81,72 (from good to superior). The application of financial management leads to the application of financial inclusion, while the achievement of value added was IDR 83,200 / liter in June 2019 and IDR 95,681 / liter in July 2019.
\end{abstract}

Keywords: cost; price; hayami; profit; wages

Abstrak: Pengabdian kepada masyarakat bertujuan meningkatkan pemahaman dan penerapan manajemen keuangan pada unit bisnis agroindustri "Andana" VCO, serta mengukur kinerja pembiayaannya. Pengabdian kepada masyarakat dilaksanakan dengan metode literasi, tutorial dan pendampingan. Pemahaman peserta tutorial atas manajemen keuangan diukur dari hasil pre test dan post test, sementara penerapan manajemen keuangan dinilai dari inklusi keuangan, serta kinerja pembiayaan diukur menggunakan alat analisis nilai tambah. Hasil kegiatan pengabdian menunjukkan bahwa pemahaman manajemen keuangan meningkat dari 77,69 menjadi 81,72 (dari baik ke unggul). Penerapan manajemen keuangan mengarah kepada penerapan inklusi keuangan, sementara capaian nilai tambah $\mathrm{Rp}$ 83.200/liter pada bulan Juni 2019 dan Rp 95.681/liter pada bulan Jui 2019.

Kata Kunci: biaya; harga; hayami; laba; upah

\section{PENDAHULUAN}

Minyak kelapa dara dihasilkan dari ekstrak daging kelapa tua. Dalam perdagangan disebut VCO (Virgin Coconut Oil). VCO berhasiat bagi pemeliharaan kesehatan karena dapat meningkatkan High Density Lipoprotein (HDL) dan mengurangi Low Density Lipoprotein (LDL); melindungi tumbuh dari mikroorganisme berbahaya, karena mengandung asam laurat yang dapat diubah oleh tumbuh menjadi monolaurin yang mampu membasmi berbagai jenis patogen berbahaya seperti bakteri, virus, dan jamur; meniurunkan berat badan, karena dapat meningkatkan ketersediaan energi dalam tumbuh dan mengurangi rasa lapar; mengatasi semblit atau susah buang air, mengobati tukak lambung, mencegah 
iritasi pada usus, dan meningkatkan kinerja sistem percernakaan; menjaga kesehatan gigi dan mulut, karena dapat membasmi berbagai bakteri dalam mulut (Anonim, 2019a'Anonim, 2019b).

Minyak kelapa murni telah menjadi komoditas perdagangan di berbagai daerah dan diproduksi dalam skala usaha rumah tangga, diantaranya di Kabuaten Nias, Lampung, Bengkulu, Yogyakarta ( Peirera, 2019, Nabiu, et al., 2006, Dindy, 2006) dan diproduksi di Kabupaten Lombok Utara (Tajidan, et al, 2019). Berbagai hasil penelitian mengungkapkan bahwa pengolahan buah kelapa tua menjadi VCO menghasilkan nilai tambah dan memberikan manfaat ekonomi bagi para pelaku usaha. Hasil penelitian di Kota Bengkulu mengungkapkan bahwa nilai tambah yang diperoleh dari pengolahan VCO berkisar Rp2,082/butir sampai dengan Rp2.576/butir (Nabiu, et al., 2006); Dindy (2006) dengan menggunakan metode Hayami menyimpulkan bahwa nilai tambah yang diperoleh perajin sebagai plasma lebih kecil bila dibandingkan nilai tambah yang diperoleh perusahaan sebagai inti. Penelitian yang dilakukan oleh Supanji dan Endang (2016) di Kabupaten Natuna pada periode panen 2014. Dengan menggunakan metode Hayami menghasilkan nilai tambah Rp952/liter dari input kelapa segar dan Rp376/liter dari kelapa kopra.

Penggunaan metode Hayami dalam analisis nilai tambah banyak digunakan oleh para peneliti (Dindy, 2006; Supanji dan Endang, 2016) memiliki kemudahan, karena telah dilengkapi dengan formul yang terstruktur, sehingga tersedia guiden bagi para peneliti dan beberapa analisis kontribusi komponen biaya dalam pembentukan nilai tambah. Metode Hayami memberikan informasi tambahan nilai dari input menjadi ouput, namun tidak dapat menggambarkan pihak yang menerima manfaat dari nilai tambah tersebut.

Era melium dewasa ini, pembangunan difokuskan pada pembangunan sumberdaya manusia, yaitu pembangunan yang bermanfaat bagi manusia dalam rangka peningkatan kesejahteraannya dalam hal ini adalah para pelaku usaha. Pelaku usaha terdiri atas pengusaha dan tenega kerja. Pelaku usaha menerima manfaat dari laba, sementara tenaga kerja mendapatkan manfaat dari upah tenaga kerja. Kelemahan metode Hayami tidak menghitung berapa proxi yang diterima pengusaha dan berapa proxi yang diterima tenaga kerja, sehingga dapat diketahu I kontribusi masing-masing pihak yang berpatisipasi dalam pembentukan nilai tambah.

Secara ekplisit bahwa nilai tambah adalah marjin dari nilai oputput dikurangi nilai input per unit output. Jadi nilai tambah adalah laba kotor per unit produksi sebelum dikurangi upah tenaga kerja per unit produksi. Dengan kata lain, nilai tambah adalah jumlah dari laba ditambah upah tenaga kerja.

Dengan meminjam catatan keuangan Unit Bisnis “Andana” VCO yang telah didampingi selama proses penumbuhan dan pengembangan agroindustri VCO di Kabupaten Lombok Utara pad bulan Juni dan Juli tahun 2019, maka dilakukan simulasi perhitungan nilai tambah yang dihasilkan selama 2 (dua) bulan untuk membuktikan bahwa nilai tambah = laba + upah tenaga kerja.

Tujuan kegiatan pengabdian adalah meningkatkan pemahaman dan penerapan manajemen keuangan unit bisnis agroindustri VCO dan mengukur kinerjanya menggunaan analisis profitabilitas.

\section{METODE}

\section{Waktu dan Tempat Pelaksanaan}

Pelaksanaan pendampingan dari bulan Juni 2019 sampai dengan bulan Juli 2019 di Unit Bisnis Agroindustri “Andana” VCO di Dusun Karang Kates Desa Gondang Kecamatan Gangga Kabupaten Lombok Utara. 


\section{Metode Pelaksanaan}

Tujuan pengabdian dicapai dengan menerapkan metode literasi, tutorial dan pendampingan. Metode literasi dilaksanakan dengan strategi penugasan. Metode tutorial dilaksabakan dengan metode ceramah (Gambar 1). Metode pendampingan dilaksanakan dengan melakukan kunjungan di lokasi tempat usaha dan memberikan pengarahan dan contoh tentang tatacara penysunan pembukuan sederhana, analisis laba rugi dan perhitungan nilai tambah (Gambar 2).
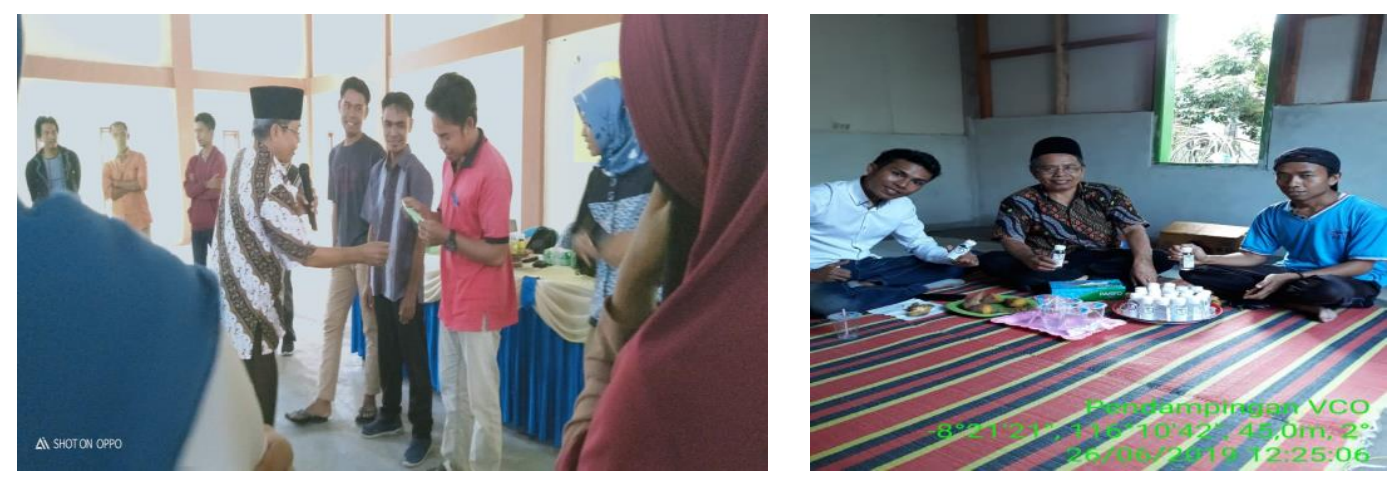

Gambar 1. Suasana Pre Test Peserta Literasi dan Tutorial (kiri) dan Pendampingan Literasi Keuangan dan Analisis Laba Rugi dan Nilai Tambah (kanan)

\section{Sasaran Literasi dan Pendampingan}

Sebagai subyek sasaran literasi dan pendampingan adalah pengusaha dan reseler VCO. Obyek sasarannya agar peserta memiliki kemampuan menyusun pembukuan sederhana, menghitung laba dan nilai tambah.

\section{Tahapan Pelaksanaan Kegiatan}

Kegiatan dilaksanakan dengan tahapan sebagai berikut:

Tabel 1. Tahapan Pelaksanaan Kegatan dan Hasil Pencapaian

\begin{tabular}{|c|c|c|}
\hline No & Tahapan Pelaksanaan Kegiatan & Hasil Pecapaian \\
\hline 1. & Negosiasi waktu dan tempat pelaksanaan & Menyepakati jadwal dan tempat pelaksanaan \\
\hline 2. & Pembagian tugas penyusunan materi & Tersedianya materi pendampingan \\
\hline 3. & Koordinasi pembiyaan & Menyepakati kontribusi media pembelajaran \\
\hline 4. & Pengadaan Kit pembelajaran & Tersedianya Kit pembelajaran \\
\hline 5. & Pelaksanaan pre test & $\begin{array}{l}\text { Mendapatkan data penguasaan materi sebelum } \\
\text { pelaksanaan }\end{array}$ \\
\hline 6. & Pelaksanaan literasi dan pendampingan & $\begin{array}{l}\text { Terlaksananya kegiatan literasi dan } \\
\text { pendampingan }\end{array}$ \\
\hline 7. & Pelaksanaan post test & $\begin{array}{l}\text { Mendapatkan data penguasaan materi setelah } \\
\text { pelaksanaan }\end{array}$ \\
\hline 8. & Monitoring praktik pembukuan sederhana & $\begin{array}{l}\text { Diterapkannya pembukuan sederhana, } \\
\text { perhitungan laba dan nilai tambah }\end{array}$ \\
\hline 9. & Evaluasi & $\begin{array}{l}\text { Mengetahui capaian hasil, kendala dan } \\
\text { hambatan, serta progres penerapan literasi dan } \\
\text { pendampingan }\end{array}$ \\
\hline
\end{tabular}




\section{HASIL DAN PEMBAHASAN}

\section{Materi Literasi dan Tutorial}

\section{Pembukuan Sederhana}

Konsep tentang manajemen keuangan sederhana para peserta umumnya telah memiliki pengetahuan yang memdai, sehingga apa yang dihajatkan tidak mulai dari awal, melainkan peserta telah memiliki bekal yang cukup untuk menerima materi pembelajaran, bahkan di antara mereka kritis dalam menerima menelaah materi pre test. Hal ini didukung oleh hasil pre test yang rata-rata mencapai 77,69 atau sangat baik.

Aliran kas masuk dan aliran kas keluar merupakan transaksi yang paling banyak terjadi dalam kegiatan ekonomi usaha kecil seperti pada Unit Bisnis Agroindustri berskala rumah tangga, karena sebagian besar transaksi menggunakan uang tunai, sebagian kecil berupa pihutang dagang atau hutang biaya. Oleh karena ada 3 (tiga) jenis transaksi yaitu kas, pihutang dagang, dan hutang biaya, maka bagi dibutuhkan 3 (tiga) jenis buku tersebut.

Transaksi dicatat langsung pada buku kas, buku pihutang dan buku hutang tanpa melalui menyusun jurnal. Selanjutnya dibuatkan rekapitulasi cash flow sevafai berikut:

Tabel 2. Aliran Kas Unit Bisnis Agroindustri “Andana” VCO

\begin{tabular}{|c|c|c|c|c|c|}
\hline \multirow{2}{*}{ No } & \multirow{2}{*}{ URAIAN } & \multicolumn{2}{|c|}{ Juni 2019} & \multicolumn{2}{|c|}{ Juli 2019} \\
\hline & & D & K & D & K \\
\hline 1 & Saldo awal (Rp) & 0 & & 1.094 .000 & \\
\hline 2 & Penerimaan (Rp) & 2.520 .000 & & 2.015 .000 & \\
\hline 3 & Pengeluaran (Rp) & & 1.426 .000 & & 1.480 .500 \\
\hline 4 & Saldo akhir (Rp) & & 1.094 .000 & & 1.628 .500 \\
\hline
\end{tabular}

\section{Perhitungan Laba}

Tujuan Unit Bisnis Agroindustri VCO adalah mendapatkan keuntungan (laba). Laba diperoleh dari selisih nilai penjualan dengan jumlah biaya yang dikorbankan. Nilai penjualan merupakan hasil kali produksi dengan harga per unit produksi, sementara jumlah biaya adalah penjumlahan seluruh biaya yang terdiri atas biaya tetap dan biaya variabel. Formulasi matematiknya sebagai berikut:

$$
\begin{aligned}
& \mathrm{L}=\mathrm{NP}-\mathrm{JB} \\
& \mathrm{NP}=\mathrm{P} \times \mathrm{Hp} \\
& \mathrm{JB}=\mathrm{BT}+\mathrm{BV}
\end{aligned}
$$

Keterangan:

$$
\begin{aligned}
& \mathrm{L}=\text { laba } \\
& \mathrm{NP}=\text { nilai produksi } \\
& \mathrm{JB}=\text { jumlah biaya } \\
& \mathrm{P}=\text { produksi } \\
& \mathrm{Hp}=\text { harga per unit produksi } \\
& \mathrm{BT}=\text { jumlah biaya tetap } \\
& \mathrm{BV}=\text { jumlah biaya variabel }
\end{aligned}
$$

Biaya tetap adalah biaya yang digunakan beberapa kali proses produksi, terdiri dari sewa tempat, bunga modal, penyusutan alat, dan pajak. Biaya variabel adalah biaya yang habis dipakai dalam satu kali proses produksi, proses produksi berikutnya diperoleh melalui pengadaan. Biaya 
variabel terdiri dari biaya bahan baku dan biaya bahan penolong. Biaya bahan baku adalah biaya yang melekat dalam produk atau menjadi bagian dari produk. Sebagai bahan baku VCO adalah daging buah kelapa tua. Biaya bahan penolong adalah biaya yang dikorbankan untuk membantu proses produksi dan tidak melekat dalam produk. Bahan penolong dalam proses produksi VCO adalah listrik, kapas, kertas saring (tissue), transport, pengemas dan label.

Dalam periode pendampingan dari bulan Juni sampai dengan bulan Juli 2019 telah dilakukan perhitungan laba rugi sebagai berikut:

Tabel 3. Penerimaan, Biaya dan Laba Unit Bisnis Agroindustri “Andana” VCO

\begin{tabular}{|c|c|c|c|}
\hline No & Uraian & \multicolumn{2}{|c|}{ Nilai (Rp) } \\
\hline \multirow[t]{2}{*}{ I. } & PENERIMAAN & & \\
\hline & Penjualan & & 4.315 .000 \\
\hline II & BIAYA-BIAYA & & \\
\hline 1 & Biaya Bahan Baku & 1.087 .500 & \\
\hline 2 & Biaya kemasan & 568.000 & \\
\hline 3 & Biaya penyaring & 14.000 & \\
\hline 2 & Biaya tisue & 47.000 & \\
\hline 5 & Biaya penyusutan alat & 15.389 & \\
\hline$\epsilon$ & Biaya Air & 50.000 & \\
\hline 7 & Biaya listrik & 40.000 & \\
\hline$\varepsilon$ & Upah TK & 700.000 & \\
\hline & Jumlah Biaya & & 2.521 .889 \\
\hline III & Laba & & 1.793 .111 \\
\hline
\end{tabular}

Dengan menggunakan data pada penerimaan dan biaya-biaya di atas dapat diketahui bahwa R/C Ratio sebesar 1,71 lebih tinggi daripada R/C Ratio pengolahan kelapa menjadi VCO di Kabupaten Natuna sebesar 1,34 (S.Setiawan dan E.Purwanti, 2016). Nilai R/C Ratio pengolahan buah kelapa tua menjadi $\mathrm{VCO}>1$, artinya bisnis produksi VCO menguntungkan dengan tingkat keuntungan sebesar $71,10 \%$ atau rata-rata $35,55 \% /$ bulan. Capaian tingkat profitabilitas lebih tinggi daripada tingkat bunga kredit komersial sebesar $1 \%$ per bulan. Dinilai dari kapasitas usaha, maka memungkinkan untuk pengembangan dengan skala usaha yang lebih besar melalui penambahan modal sendiri ataupun modal pinjaman.

Penelitian yang dilakukan oleh Nabiu, et al (2016) pada tiga agroindustri VCO di Kota Bengkulu menunjukkan bahwa profitabilitas berkisar antara 46\% sampai dengan 55\% satu kali proses produksi. Bila dibandingkan dengan profitabilitas Unit Bisnis Agroindustri VCO "Andana" dalam 7 (tujuh) kali proses produksi, maka skala profitabilitas tiga perusahaan agroindustri di Kota Bengkulu tersebut lebih tinggi. Patut diduga bahwa profitabilitas terkait dengan skala produksi setiap kali proses produksi, sebab semakin besar skala produksi, maka terjadi efisiensi dalam pemanfaatan sumberdaya perusahaan.

Konsep laba rugi umumnya telah dipahami dan diketahui oleh peserta, yaitu laba = penerimaan dikurangi jumlah biaya. Demikian pula format buku kas mereka telah ketahui, meskipun harus diakui bahwa hampir semua peserta belum memiliki catatan keuangan yang mudah dibaca dan dipahami publik. Dari aspek penguasaan konsep umumnya peserta telah paham dengan nilai post test 81,71\%. 
Bila dikomparatifkan antara nilai pre test dan post test terdapat peningkatan sebanyak 4,02\%. Peningkatan relatif kecil disebabkan peserta umumnya telah paham tentang pentingnya manajemen keuangan, khususnya untuk memisahkan keuangan rumah tangga dengan keuangan unit bisnis.

\section{Pendampingan}

\section{Perhitungan Nilai Tambah}

Nilai tambah diperoleh dari marjin nilai produksi dengan biaya bahan baku dan biaya bahan penolong. Nilai tambah per unit produksi = harga jual per unit produksi - (biaya bahan baku per unit produksi + biaya bahan penolong per unit produksi. Nilai tambah per liter $\mathrm{VCO}=$ harga jual per liter $\mathrm{VCO}$ - (biaya bahan baku per liter VCO + biaya bahan penolong per liter VCO). Formulasi matematiknya sebagai berikut:

$$
\mathrm{NT}=\mathrm{Hj}-(\mathrm{BBB}+\mathrm{BBP})
$$

Keterangan:

$\mathrm{NT}=$ nilai tambah

$\mathrm{Hj}$ = harga jual per liter

$\mathrm{BBB}=$ biaya bahan baku per liter

$\mathrm{BBP}=$ biaya bahan penolong per liter.

Nilai tambah dapat pula dihitung dari jumlah laba dan upah tenaga kerja. Formula matematiknya adalah:

$\mathrm{NT}=\mathrm{LK}+\mathrm{UTK}$

Keterangan:

$\mathrm{NT}=$ nilai tambah

LK = laba atau keuntungan atau profit kotor

UTK = upah tenaga kerja

$\mathrm{NT}=\mathrm{NT}$

$\mathrm{Hj}-(\mathrm{BBB}+\mathrm{BBP})=\mathrm{LK}+\mathrm{UTK}$

$\mathrm{Hj}-(\mathrm{BBB}+\mathrm{BBP})=\mathrm{LK}+\mathrm{UTK}$

$\mathrm{LK}=\mathrm{Hj}-(\mathrm{BBB}+\mathrm{BBP}+\mathrm{UTK})$

\section{Metode Hayami}

Prinsip metode Hayami adalah menghitung nilai tambah ber unit produk. Metode Hayami lebih sesuai digunakan pada pengukuran nilai tambah produk industri atau agroindustri, kurang tepat jika digunakan untuk usahatani ataupun usaha perdagangan dan jasa. Untuk produk dari bahan baku cair untuk diolah menjadi produk padat memerlukan modifikasi agar lebih mudah dalam penggunaannya.

Kelebihan dari Metode Hayami adalah memiliki ragam analisis diantaranya aktor konversi, koefisien tenaga kerja, ratio nilai tambah, pangsa tenaga kerja, tingkat keuntungan, dan marjin. Kelemahannya adalah sulit diterapkan apabila komponen jenis bahan bakunya banyak, jenis bahan penolongnya banyak.

\section{Metode Marjin Kontribusi}

Marjin kontribusi adalah selisih antara harga produk per unit dengan biaya bahan baku per unit dan biaya bahan penolong per unit. Metode ini sesuai digunaan pada berbagai kegiatan ekonomi 
manufator (industri dan agroindustri), agribisnis, estate, perdagangan maupun jasa. Selain dapat menghitung nilai tambah per unit, juga dapat menghitung nilai tambah unit bisnis (mikro) maupun wilayah (makro). Keuntungan lainnya adalah tidak perlu mengetahui faktor konversi, penggunaan tenaga kerja dan upah tenaga kerja, sehingga perhitungan lebih mudah.

Tabel 4. Variabel dan Nilai Metode Hayami

\begin{tabular}{cll}
\hline No & \multicolumn{1}{c}{ Variabel } & \multicolumn{1}{c}{ Nilai } \\
\hline I. & Output, Input dan Harga & $(1)$ \\
1 & Output (liter) & $(2)$ \\
2 & Input (liter) & $(3)$ \\
3 & Tenaga kerja (liter) & $(4)=(1) /(2)$ \\
4 & Faktor Konversi & $(5)=(3) /(1)$ \\
5 & Koefisien tenaga kerja (HKO/liter) & $(6)$ \\
6 & Harga output (Rp/liter) & $(7)$ \\
7 & Upah tenaga kerja (Rp/HKO) & $(8)$ \\
II. & Penerimaan dan Keuntungan & $(9)$ \\
8 & Harga bahan baku (Rp/liter) & $(10)=(4) \times(6)$ \\
9 & Sumbangan input lain (Rp/liter) & $(11 \mathrm{a})=(6)-(8)-(9)$ \\
10 & Nilai output (Rp/liter) & $(11 \mathrm{~b})=(11 \mathrm{a} / 10) \times 100$ \\
11 & a. Nilai tambah (Rp/liter) & $(12 \mathrm{a})=(5) \times(7)$ \\
& b. Ratio nilai tambah (\%) & $(12 \mathrm{~b})=(12 \mathrm{a} / 11 \mathrm{a}) \times 100$ \\
12 & a. Pendapatan tenaga kerja (Rp/kg) & $(13 \mathrm{a})=11 \mathrm{a}-12 \mathrm{a}$ \\
& b. Pangsa tenaga kerja (\%) & $(13 \mathrm{~b})=(13 \mathrm{a} / 11 \mathrm{a}) \times 100$ \\
13 & a. Keuntungan (Rp/liter) & $(14)=(10)-(8)$ \\
III. & balas Jasa Pemilik Faktor Produksi & $(14 \mathrm{a})=(12 \mathrm{a} / 14) \times 100$ \\
14 & Marjin (Rp/kg) & $(14 \mathrm{~b})=(9 / 14) \times 100$ \\
& a. Pendapatan tenaga kerja (Rp/liter) & $(14 \mathrm{c})=(13 \mathrm{a} / 14) \times 100$ \\
\hline
\end{tabular}

Sumber: Metode Hayami, et al., 1987 dimodifikasi,

Tabel 5. Variabel dan Nilai Metode Marjin Kontribusi

\begin{tabular}{rlccl}
\hline \multicolumn{1}{c}{ No } & \multicolumn{1}{c}{ Variabel } & Unit & Harga/ Unit & \multicolumn{1}{c}{ Nilai } \\
\hline I & a.Penerimaan (Rp/liter) & (a1) & (a2) & $(\mathrm{a})=(\mathrm{a} 1 \mathrm{xa} 2)$ \\
II & b.Biaya (Rp/liter) & & & $(\mathrm{b})=(\mathrm{b} 1+\mathrm{b} 2)$ \\
& b1.Bahan Baku (Rp/liter) & $(\mathrm{b} 11)$ & $(\mathrm{b} 12)$ & $(\mathrm{b} 1)=(\mathrm{b} 11 \mathrm{xb} 12)$ \\
& b2.Bahan Penolong (Rp/liter) & & & $(\mathrm{b} 2)$ \\
III & c.Nilai Tambah & & & $(\mathrm{c})=(\mathrm{a})-(\mathrm{b})$ \\
& c1.Nilai Tambah (Rp/liter) & & & $(\mathrm{c} 1)=(\mathrm{c} / \mathrm{a} 1)$ \\
\hline
\end{tabular}

\section{Analisis Nilai Tambah}

\section{Metode Hayami}

Pada bulan Juni 2019 terlaksana 3 (tiga) kali proses produksi, bahan baku 150 butir kelapa, jumlah produksi 10 liter. Pada bulan Juli 2019 sebanyak 4 (empat) kali proses produksi, bahan baku 225 butir kelapa, dan jumlah produksi 18, 4 liter. Semakin banyak jumlah bahan baku yang diolaj menghasilkan nilai tambah yang lebih besar, terutama pada komponen laba. Efisiensi penggunaan 
sumberdaya dimungkinkan apabila ditingkatkan skala usaha, dan peningkatan kapasitas usaha. Hasil analisis menunjukkan bahwa dengan peningkatan penggunaan jumlah proses produksi dan peningkatan jumlah bahan baku berdampak bagi peningkatan efiiensi penggunaan modal dan efisiensi penggunaan sumberdaya.

Tabel 6. Perhitungan Nilai Tambah Menggunakan Metode Hayami

\begin{tabular}{|c|c|c|c|c|}
\hline No & Varibel & Nilai & Juni 2019 & Juli 2019 \\
\hline I. & Output, Input dan Harga & & & \\
\hline 1 & Output (liter) & (1) & 10 & 18,4 \\
\hline \multirow[t]{2}{*}{2} & a. Input (butir) & (2a) & 150 & 225 \\
\hline & b. Input (butir/liter) & $(2 b)=(2 a) /(1)$ & 15 & 12,23 \\
\hline 3 & Tenaga kerja (liter) & (3) & 3 & 4 \\
\hline 4 & Faktor Konversi & $(4)=(1) /(2 a / 2 b)$ & 1 & 1 \\
\hline 5 & Koefisien tenaga kerja (HKO/liter) & $(5)=(3) /(1)$ & 0,30 & 0,22 \\
\hline 6 & Harga output (Rp/liter) & (6) & 152.000 & 151.900 \\
\hline 7 & Upah tenaga kerja $(\mathrm{Rp} / \mathrm{HKO})$ & (7) & 100.000 & 100.000 \\
\hline II. & Penerimaan dan Keuntungan & & & \\
\hline \multirow[t]{2}{*}{8} & a. Harga bahan baku (Rp/butir) & (8a) & 3.000 & 2.833 \\
\hline & b. Harga bahan baku (Rp/liter) & $(8 b)=(8 a \times 2 b)$ & 45.000 & 34.643 \\
\hline 9 & Sumbangan input lain (Rp/liter) & (9) & 23.200 & 21.576 \\
\hline 10 & Nilai output (Rp/liter) & $(10)=(4) \times(6)$ & 152.000 & 151.900 \\
\hline \multirow[t]{2}{*}{11} & a. Nilai tambah (Rp/liter) & $(11 a)=(6)-(8 b)-(9)$ & 83.800 & 95.681 \\
\hline & b. Ratio nilai tambah (\%) & $(11 \mathrm{~b})=(11 \mathrm{a} / 10) \times 100$ & 55,13 & 62,99 \\
\hline \multirow[t]{2}{*}{12} & a. Pendapatan tenaga kerja (Rp/liter) & $(12 \mathrm{a})=(5) \times(7)$ & 30.000 & 21.739 \\
\hline & b. Pangsa tenaga kerja $(\%)$ & $(12 b)=(12 a / 11 a \times 100$ & 35,80 & 22,72 \\
\hline \multirow[t]{2}{*}{13} & a. Keuntungan (Rp/liter) & $(13 a)=11 a-12 a$ & 53.800 & 73.942 \\
\hline & b. Tingkat keuntungan $(\%)$ & $(13 b)=(13 a / 11 a) \times 100$ & 64,2005 & 77,28 \\
\hline III. & Balas Jasa Pemilik Faktor Produksi & & & \\
\hline \multirow[t]{4}{*}{14} & Marjin $(\%)$ & $(14)=(10)-(8 b)$ & 149.000 & 117.257 \\
\hline & a. Pendapatan tenaga kerja $(\%)$ & $(14 a)=(12 a / 14) \times 100$ & 20,13 & 18,54 \\
\hline & b. Sumbangan input lain (\%) & $(14 b)=(9 / 14) \times 100$ & 15,57 & 18,40 \\
\hline & c. Keuntungan pengusaha (\%) & $(14 c)=(13 a / 14) \times 100$ & 36,11 & 63,06 \\
\hline
\end{tabular}

Pada bulan Juni 2019, laba atau keuntungan + pendapatan (upah) tenaga kerja = Rp53.800 + Rp30.000 = Rp83.800. Hasil penjumlahan ini sama dengan nilai tambah sebesar Rp83.800. Pada bulan Juli 2019, laba + upah tenaga kerja = Rp73.942 + Rp21.739 = Rp95.681. Hasil penjumlahnya sama dengan nilai tambah sebesar Rp95.681. Dengan demikian dapat dibuktikan bahwa nilai tambah = laba + upah tenaga kerja.

Dalam 2 (dua) bulan pendampingan menunjukkan peningkatan produksi dari 10 liter menjadi 18,4 liter. Peningkatan produksi berkorelasi positif dengan peningkatan kuantitatif dan kuanilitatif nilai tambah dan keuntungan per liter, sementara peningkatan produksi berkorelasi negatif dengan pendapatan tenaga kerja per liter.

Faktor yang mempengaruhi nilai tambah agroindustri VCO antara lain: kapasitas produksi, jumlah bahan baku, jumlah minyak pancingan, karton outer, jumlah botol dan penutup (Dindy, 2006). Penjualan VCO curah tampaknya kurang menguntungkan bagi produsen plasma, namun memberikan keuntungan ekstra bagi perushaan inti. Hal ini sesuai dengan keluhan produsen VCO bahwa menjual VCO curah tidak banyak menghasilkan kentungan, karena dibayar dengan harga yang murah yaitu Rp50.000/liter, sementara bila telah dikemas laku terjual seharga Rp 15.000/botol, satu botol dengan 
ukuran 100ml atau 0,1 liter. Bila dikemas laku terjual Rp 150.000/liter. Dengan demikian dari VCO curah ke VCO botol terjadi kenaikan harga 3 (tiga) kali lebih tinggi.

\section{Metode Marjin Kontribusi}

Metode marjin kontribusi menghasilkan nilai tambah yang sama dengan metode Hayami, kalaupun ada perbedaan namun perbedaan tidak signifikat sebagai akibat dari interger atau pembulatan. Pada bulan Juni 2019 diperoleh nilai tambah Rp83.800/liter, dan pada bulan Juli 2019 nilai tambah sebesar Rp95.679,5/liter. Peningkatan nilai tambah antara lain disebabkan jumlah penggunaan bahan baku yang lebih banyak, dan nilai pembelian bahan baku per butir yang lebih murah (Putri, 2006).

Tabel 7. Perhitungan Nilai Tambah Metode Marjin Kontribusi

\begin{tabular}{llrrrrrr}
\hline \multirow{2}{*}{ No } & \multicolumn{1}{c}{ Uraian } & \multicolumn{3}{c}{ Juni 2019} & \multicolumn{3}{c}{ Juli 2019} \\
& & Unit & Harga/liter & Nilai(Rp) & Unit & Harga/liter & \multicolumn{1}{c}{ Nilai(Rp) } \\
\hline 1 & a.Penerimaan & 10,0 & 152.000 & 1.520 .000 & 18,4 & 151.900 & 2.795 .000 \\
2 & b.Biaya & & & 682.000 & & & 1.034 .500 \\
2.1 & b1.Bahan Baku & 150 & 3.000 & 450.000 & 225 & 2.833 & 637.500 \\
2.2 & b2.Bahan Penolong & & & 232.000 & & & 397.000 \\
2.2 .1 & b21.Botol & 100 & 2.000 & 200.000 & 184 & 2.000 & 368.000 \\
2.2 .2 & b22.Kertas Tissue & 2 & 12.000 & 24.000 & 2 & 11.500 & 23.000 \\
2.2 .3 & b23.Kapas & 4 & 2.000 & 8.000 & 3 & 2.000 & 6.000 \\
& c.Nilai Tambah & & & 838.000 & & & 1.760 .500 \\
& c1.Nilai Tambah (Rp/ltr) & & & 83.800 & & & $95.679,5$ \\
\hline
\end{tabular}

Sumber: Tajidan, et al, 2019.

Peningkatan penggunaan bahan baku dari bulan Juni ke Juli sebesar 50\% menghasilkan peningkatan nilai tambah sebesar $110 \%$ pada periode yang sama, sedangkan peningkatan biaya sebesar 51,69\%. Dari analisis ini dapat diketahui bahwa peningkatan jumlah bahan baku dapat menurunkan biaya produksi rata-rata dari Rp68,200/liter menjadi Rp56,223/liter, kecuali biaya botol kemasan yang konstan sebesar Rp2.000/botol berapapun jumlah produksi. Harga kelapa yang relatif murah, ikut berkontribusi terhadap peningkatan nilai tambah dan sebaliknya. Pada bulan Juni 2019 harga kelapa Rp3.000/butir, sementara pada bulan Juli 2019 Rp2.833/butir. Demikian juga harga kertas tissue pada bulan Juni 2019 Rp12.000/kotak menjadi Rp11.500/kotak. Harga penjualan VCO juga menurun Rp100/liter dari Rp 152.000/liter menjadi Rp151.900/liter.

\section{Evaluasi Pre Test dan Post Test}

Pengukuran atas pemahaman tentang pembiayaan dilakukan evaluasi yang terdiri atas evaluasi sebelum tutorial (pre test) dan evaluasi setelah tutorial (post test). Materi pre test sama dengan materi post test. Hasilnya menjunkkan bahwa peserta telah memiliki pengetahuan yang cukup tentang materi yang disajikan sebagai dampak telah dilakukan pendampingan sejak bulan Juni 2019 sampai dengan akhir Juli 2019. Hasil pre test menujukkan bahwa rata-rata nilai yang diperoleh adalah 77,69. Pada akhir pelaksanaan literasi pembiayaan dilakukan post test dengan perolehan nilai 81,72 ; artinya ada peningkatan dari hampir unggul menjadi unggul (Tajidan, et al., 2019) 


\section{Kesimpulan}

\section{KESIMPULAN DAN SARAN}

Hasil kegiatan pengabdian menunjukkan bahwa pemahaman manajemen keuangan meningkat dari 77,69 menjadi 81,72 (dari baik ke unggul). Penerapan manajemen keuangan mengarah kepada penerapan inklusi keuangan, sementara capaian nilai tambah Rp 83.200/liter pada bulan Juni 2019 dan Rp 95.681/liter pada bulan Juli 2019.

\section{Saran}

Kerjasama pendampingan dalam rangka pengembangan agroindustri VCO sedapat mungkin dilanjutkan agar kelompok masyarakat mendapatkan manfaat dan memperoleh peningkatan pendapatan dari kegiatan usaha ekonomi produktifnya. Kepada pengusaha VCO diharapkan mengadopsi manajemen keuangan agar skala usaha dan penghasilannya meningkat.

\section{Ucapan Terima Kasih}

Terima kasih disampaikan kepada Muharal Muslim atas kerjasama dalam pelaksanaan kegiatan pendampingan, dan terima kasih pula kepada semua pihak yang telah berkontribusi bagi terselenggaranya kegiatan pengabdian kepada masyarakat. Semoga sumbangsih dan dukungannya menjadi bagian dari amal ibadah masing-masing.

\section{DAFTAR PUSTAKA}

Anonim, 2019a. Manfaat Virgin Coconut Oil U Untuk Kesehatan. https://hellosehat.com>manfaat [Diunduh tanggal 7 Agustus 2019]

Anonim, 2019b. Manfaat VCO Untuk Kesehatan. https://doktersehat.com [Diunduh tanggal 7 Agustus 2019]

Nabiu, M., Ellys Yulirti, Esteria Manurung, 2006. Analisis Nilai Tambah dan Kemampulabaan Tiga Agroindustri VCO di Kota Bengkulu. https://ejournal.unib.ac.id. Diunduh tanggal 7 Agustus 2019.

Dindy Darmayanti Putri, 2006. Analisis Nilai Tambah VCO Pengrajin Plasma dan Inti PT Patria Wiyata Vico Yogyakarta. Etd.repository.ugm.ic.id. Diunduh tanggal 7 Agustus 2019.

Pereira, M.M., 2019. Analisis Nilai Tambah Virgin Coconut Oil Di Kabupaten Nias Selatan Sumatera Utara. Fakultas Pertanian Univeritas Udaya. Denpasar.

Supanji Setiawan dan Endang Purwanti, 2016. Nilai Tambah dan Profitabilitas Komoditas Kelapa di Kabupaten Natuna. Jurnal.untidar.ac.id. Diunduh tanggal 7 Agustus 2019.

Tajidan, Halil, Efendy dan FX Edy Fernandes, 2019. Pendampingan Pembiayaan Pada Unit Bisnis Agroindustri Minyak Kelapa Dara di Kabupaten Lombok Utara. Jurnal Ilmiah Abdi MAS TPB Volume 1 Nomor 2. Bulan Juli 2019. www.abdimastpb.unram.ac.id. 